\title{
5．海色センサーによる基礎生産力推定モデル
}

\section{浅沼 市男*}

\section{1.はじめに}

海洋における基礎生産力とは, 植物プランクトンに 含まれるクロロフィル-aの光合成過程における炭素 同化の速度を示す変数である。基礎生産力は, 海水中 の生物化学循環の一つでありながら, 全球べースの視 点から見たとき，大気と海洋間の二酸化炭素の移送を 推定するため必要な, 海水中の生物化学循環を示す変 数の一つである (Saba et al., 2011)。また, 基礎生産 力の推定モデルは, 海洋表層混合層から深層への有機 物としての移送を示す輸出生産の評価指標であり, 気 候変動へ貢献するとされる植物プランクトンによるジ メチル・サルファイドの生産量推定の指標でもある。 さらに，海洋の動物プランクトンから魚類までの生態 系の連鎖関係を説明する生化学モデルにおいても，基 礎生産力モデルは重要な構成要素となる (Turk et al., 2011)。

これまで, 基礎生産力の計測は, 植物プランクトン の培養が必要なため, 船舶観測による現場法か擬似現 場法により計測されてきた(Shiomoto，1998)。現場法 とは, 透明度の高いポリカーボネート・ボトルを培養 ビンとして利用し，採水海水にラベル付き炭素であ る ${ }^{13} \mathrm{C}$ あいは ${ }^{14} \mathrm{C}$ をトレーサとして注入し, 採水深度 へボトルを投入し，植物プランクトンを培養する方法 である。疑似現場法とは，デッキ上あるいは船内の実 験室において，太陽照度と水温を疑似的に再現し，同 様に，植物プランクトンを培養する方法である。その 上で，植物プランクトンにトラップされた天然に存在 する炭素である ${ }^{12} \mathrm{C}$ とトレーサ炭素の量を分析し，基

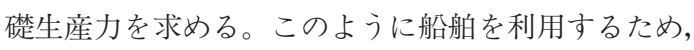
測点数が限定され, 全球べースの議論へ結びつかな かった。

この現場における基礎生産力計測のギャップを埋め るため, 衛星搭載の海色センサーによるクロロフィル - $\mathrm{a}$ 濃度分布から基礎生産力を推定するモデルの研究

*学校法人東京農業大学・東京情報大学

「写真測量とリモートセンシング」VOL. 52，NO. 5， 2013
が進められてきた(Behrenfeld and Falkowski，1997， Asanuma, 2006)。

\section{2. 基礎生産力}

海洋の植物プランクトンによる単位容積, 単位時間 （1日）当たりの基礎生産力は次式に定義される。

$\boldsymbol{P P}=\int\left(P_{g}-R_{L}-R_{d}\right) d t=\int\left(P_{n}\right) d t$

ここで, $P P$ は基礎生産力 $\left(\mathrm{mgC} \mathrm{m}{ }^{-3} \mathrm{day}^{-1}\right), \quad P_{g}$ は 総生産力 $\left(\mathrm{mgC} \mathrm{m}^{-3}\right.$ hour $\left.^{-1}\right), R_{L}$ は日中 (Light) の 呼吸による有機炭素の消費力 $\left(\mathrm{mgC} \mathrm{m}{ }^{-3}\right.$ hour $\left.^{-1}\right), R_{d}$ は夜間（dark）の呼吸による有機炭素の消費力 $(\mathrm{mgC}$ $\mathrm{m}^{-3}$ hour $\left.^{-1}\right)$ である。総生産力から消費力を差し引い た正味 (net) 生産力として $P_{n}\left(\mathrm{mgC} \mathrm{m}{ }^{-3}\right.$ hour $\left.^{-1}\right)$ が 与えられる。さらに, リモートセンシングによるクロ ロフィル- $\mathrm{a}$ 濃度分布と比較するため, 植物プランクト ンが光合成をおこなう深度までの全水柱当りの基礎生 産力として, 単位面積, 単位時間当たりの基礎生産力 $\left(\mathrm{mgC} \mathrm{m}{ }^{-2} \mathrm{day}^{-1}\right)$ が利用される。

植物プランクトンによる基礎生産力は, 表層混合層 において生産され, 動物プランクトン等による捕食, 排出, 再生産と表層混合層における炭素循環となる。 この内，沈降等により表層混合層から深層へ輸送され る炭素量をエクスポート・プロダクションと呼ぶ。ま た, 深層など表層混合層以外から供給される栄養塩に より生産される炭素量をニュー・プロダクションと呼 ぶ。衛星観測デー夕を利用する基礎生産力推定モデル においては，観測データ以外の要素が関与するエクス ポート・プロダクションあるいはニュー・プロダクショ ンは，推定の困難な変数となっている。

\section{2 - 1 . 簡易型基礎生産カモデル}

Eppley et al. (1972) などは，海色センサーから推定 されるクロロフィル- $\mathrm{a}$ 濃度について, 基礎生産力の推 定のための経験式を提案した。

$\log (\boldsymbol{P P})=a+b \cdot \log (C h l-a)$ 
ここで，PPは単位面積，単位時間当たりの基礎生産 力, Chl-a は海色センサーにより与えられるクロロ フィル- $\mathrm{a}$ 濃度, a, b は定数である。この式は, 表層の クロロフィル- $\mathrm{a}$ 濃度を基礎とするため, クロロフィル - $\mathrm{a}$ の表層極大を形成する海域では過大評価になった り，深層極大を形成する海域では過小評価となったり する問題がある。しかし，衛星観測デー夕を容易に利 用可能なモデルであった。

\section{2 - 2 . 波長解析型基礎生産カモデル}

基礎生産力について，全光合成有効波長範囲につい て波長依存性を考慮し, 日出から日没までの時間変化 を考虑し，また，表面から光合成有効深度までの空間 分布を考慮したモデルが提案された（Platt，1986）。

$$
\begin{aligned}
\boldsymbol{P P}= & \int_{\lambda=400,700} \int_{t=\text { sunrise, sunset }} \int_{z=0, E U} \phi_{(\lambda, t, z)} P A R_{(\lambda, t, z)} \\
& a^{*}{ }_{(\lambda, z)} C h l_{(z)} d \lambda d t d z
\end{aligned}
$$

ここで， $\phi$ は波長, 時間, 深度を関数とする光合成有効 照度に応じたクロロフィル-a 固有の量子効率, PAR は波長，時間，深度を関数とする光合成有効照度， $\mathrm{a}^{*}$ は波長と深度を関数とするクロロフィル-a 固有の分 光吸収係数, chl は深度ごとのクロロフィル-a 濃度を 示す。波長依存性, 時間依存性, あるいは深度依存性 を考慮すると，モデル構築と検証のためのデータベー スに強く依存することになり，海域依存型の基礎生産 カモデルとなった。

\section{$2-3$. 波長積分型基礎生産カモデル}

波長依存性を光合成有効照度について積分し，モデ ルを簡素化したものである。このモデルは, 日出から 日没まで, 表面から光合成有効照度深度までの積分と する。

$\boldsymbol{P P}=\int_{t=\text { sunrise, suns }} \int_{z=0, E U} \phi_{(t, z)} P A R_{(t, z)} \operatorname{Ch} l_{(z)} d t d z$

ここで, $\phi$ は時間, 深度を関数とする光合成有効照度に 応じたクロロフィル-a 固有の量子効率, PAR は時間, 深度を関数とする光合成有効照度, chl は深度ごとの クロロフィル- $\mathrm{a}$ 濃度を示す。波長依存性を消去するた め, クロロフィル-a の分光吸光係数は消去され, 量子 効率に光応答が含まれる。

\section{$2-4$. 時間積分型基礎生産カモデル}

さらに, モデルを簡略化し, 深度分布についての積 $-248-$
分值である。

$\boldsymbol{P P}=\int_{z=0, E U} \phi_{(z)} P A R_{(z)} C h l_{(z)} d z$

ここで， $\phi$ は深度を関数とする光合成有効照度に応じ たクロロフィル- $\mathrm{a}$ 固有の量子効率, PAR は深度を関 数とする光合成有効照度, chl は深度ごとのクロロ フィルー $\mathrm{a}$ 濃度を示す。量子効率及び光合成有効照度は 1 日当りの量となり, 時間変化を消去したモデルであ る。この場合, 極域の時間当たりの光合成有効照度が 弱いものの日照時間が長いために 1 日当りの光合成有 効照度が大きい海域と, 太陽直下の 1 日当りの光合成 有効照度の大きい海域が同じ評価となり, 植物プラン クトンの光応答が異なるものの, 同じ条件での基礎生 産力推定となる。

\section{2 - 5 . 深度積分型基礎生産力モデル}

(2)式と同様に最も単純化したモデルである。

$\boldsymbol{P P}=P^{b}{ }_{o p t} P A R_{(0)} C h l$

ここで， $P_{\text {opt }}^{b}$ はクロロフィル- $\mathrm{a}$ 固有の最適な炭素同 化効率, $\mathrm{PAR}_{(0)}$ は海面における光合成有効照度, $\mathrm{Chl}$ は表層のクロロフィル-a 濃度である。

Behrenfeld and Falkowski（1994）は，過去の基礎 生産力の計測デー夕をもとに, (6)式を発展させ, 日照 時間と光合成有効深度を解析的に与えたモデルを提案 した。

$\boldsymbol{P P}_{e u}=0.66125 P^{b}{ }_{\text {opt }}\left[E_{0} /\left(E_{0}+4.1\right)\right] Z_{e u} C_{o p t} D D_{\text {irr }}$

ここで, $P P_{e u}$ は有光層の基礎生産力 $\left(\mathrm{mgC} \mathrm{m}^{-2}\right.$ $\left.\mathrm{day}^{-1}\right), P^{b}$ opt は最適な炭素同化効率 $\left(\mathrm{mgC} \mathrm{mgChl}^{-1}\right.$ hour $\left.{ }^{-1}\right), E_{0}$ は光合成有効照度 $\left(\operatorname{Ein} \mathrm{m}^{-2} \mathrm{day}^{-1}\right), Z_{e u}$ は $1 \%$ 有光層深度 $(\mathrm{m}), C_{o p t}$ は有光層までの有効ク ロロフィル- $\mathrm{a}$ 濃度 $\left(\mathrm{mg} \mathrm{m}^{-3}\right), D_{i r r}$ は日照時間(hour) である。また，炭素同化効率は水温の関数として，次 式に与えられる。

$$
\begin{aligned}
P_{\text {opt }}^{b}= & -3.27 \cdot 10^{-8} T^{7}+3.4132 \cdot 10^{-6} T^{6}-1.348 \cdot 10^{-4} T^{5} \\
& +2.462 \cdot 10^{-3} T^{4}-0.0205 T^{3}+0.0617 T^{2} \\
& +0.2749 T+1.2956
\end{aligned}
$$

ここで，Tは水温である。この炭素同化効率の式は, これまで数值モデルなどに採用されてきた温度に対し て指数関数的に上昇する炭素同化効率と大きく異な る。このモデルは有光層の深度が変化するものの 1 層 
モデルであり，海域によっては過大評価あるいは過小 評価の問題点がある。

\section{2-6. 時間・深度解析型基礎生産力モデル}

Asanuma ら ${ }^{5}$ は, 西部北太平洋, 東シ十海, 赤道直 下の海域において ${ }^{13} \mathrm{C}$ を用いた現場法あるいは擬似現 場法による基礎生産力結果をもとに，時間・深度解析 型の基礎生産力モデルを提案した。基礎デー夕は，富 栄養海域から貧栄養海域, 低緯度から中緯度, ケース I 海域からケースII海域を含み，モデル化を試みた。

$\boldsymbol{P P}_{e u}=\int_{t} \int_{z} P_{b}\left(z, E_{(z, n o o n)}, T\right) C_{(z)} E_{(0, t)} / E_{(0, n o o n)} d z d t \quad(9$ ここで, $P_{b}$ は深度, 光合成有効照度, 水温を関数とす る炭素同化効率 $\left(\mathrm{mgC} \mathrm{mgChl}-\mathrm{a}^{-1}\right.$ hour $\left.^{-1}\right), E_{(z, t)}$ は 深度 $Z$ 及び時刻 $t$ に扔ける光合成有効照度, $C_{(z)}$ は深 度 $z$ におけるクロロフィル- $\mathrm{a}$ 濃度で，Tは水温であ る。また, 光合成有効照度の深度分布（表層照度に対 するパーセント) とクロロフィル- $\mathrm{a}$ 濃度の深度分布は 経験的に次に与えられる。

$\log \left(E_{\%(z)}\right)=\left(-0.025 C_{0}-0.017\right) Z+2$

$$
\begin{aligned}
C_{(z)}= & {\left[1-\left(0.9+0.7 C_{0}\right) \exp \left\{-0.8 E_{\%(z)}\right\}\right] } \\
& \exp \left\{-0.8 E_{\%(z)}\right\}+C_{0}
\end{aligned}
$$

また，炭素同化効率は光合成有効照度，水温，深度の 関数として経験的に次に与えられる。

$$
\begin{aligned}
P_{b(z)}= & 13\left[1-\exp \left\{-0.001 a E_{\%(z)}\right\}\right] \\
& \exp \left\{-0.004 b E_{\%(z)}\right\}+1 \\
a= & 0.1^{*} s^{*} E_{(0)}+i \\
s= & 0.0001 T^{3}+0.0036 T^{2}-0.0007 T+0.2557 \\
i= & 0.00021 T^{3}-0.0106 T^{2}+0.0868 T-0.1042 \\
b= & 0.0005 T^{3}-0.0202 T^{2}+0.1134 T+3.1214
\end{aligned}
$$

この時間・深度解析型の基礎生産力モデルは, これま での植物プランクトンの鉛直分布推定手法に対して光 合成有効照度の深度分布に依存するモデル式とし，深 層極大まで再現可能なモデルを経験的に構築した。ま た，炭素同化効率は，Behrenfeld and Falkowski (1994) が温度の関数として一意的に決定したが，海域 により適用困難な場合があったことから，光合成有効 照度に依存する炭素同化効率を経験的に与える。この モデルは， ${ }^{13} \mathrm{C}$ をトレーサとして用いた現場法及び擬 似現場法による基礎生産力測定に対して，非常に良い

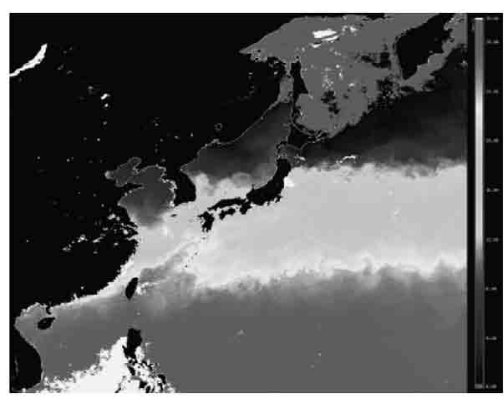

図 1 月間海表面温度分布 (MODIS/AQUA 2013年 4 月)

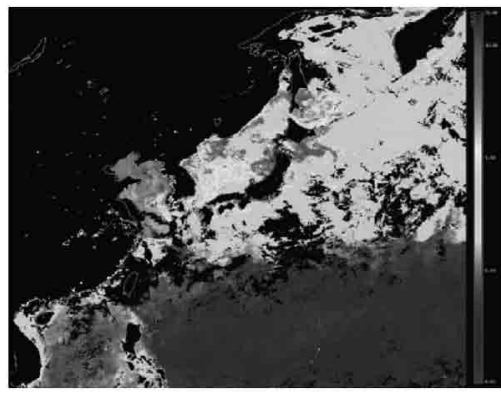

図2 月間クロロフィル- $\mathrm{a}$ 分布 (MODIS/AQUA 2013年 4 月)

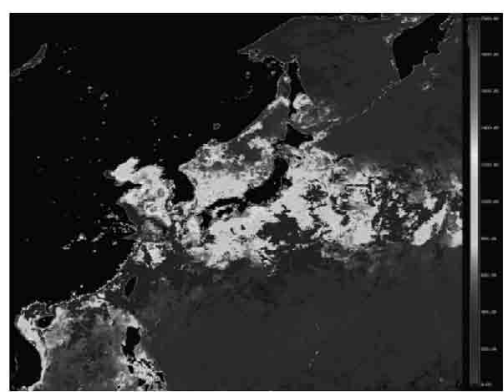

図 3 時間及び深度解析型基礎生産力推定結果 (2013年 4 月)

相関を示した。

2013年 4 月の海表面温度 $\left({ }^{\circ} \mathrm{C}\right.$ )（図 1 ), クロロフィル - $\mathrm{a}\left(\mathrm{mg} \mathrm{m}^{-3}\right)$ (図 2 ) と, 基礎生産力推定結果 ( $\mathrm{mgC}$ $\mathrm{m}^{-2} \mathrm{day}^{-1}$, 図 3 ) である。この時期は, 春の大増殖期 に当たり，東シ十海から三陸沖において，基礎生産力 の高いことが示されている。

\section{3.まとめ}

衛星搭載の海色センサーを利用した全球ベースの基 礎生産力推定モデルの研究は, 地球温暖化傾向の中, 
海洋の炭酸ガスの吸収と放出に関する貢献を評価する ため重要な研究である。現在は，大気中の二酸化炭素 濃度上昇にともなう海洋の酸性化傾向が問題化される 中，海水中の生化学反応と食物連鎖過程において，基 礎生産力推定の研究が継続されている。

\section{参考文献}

1) Asanuma, I., 2006, Depth and Time Resolved Primary Productivity Model Examined for Optical Properties of Water, Elsevier Oceanography Series, 73, pp.91-107.

2 ) Behrenfeld M.J. and P.G. Falkowski, 1997, Photosynthetic rates derived from satellite-based chlorophyll concentration, Limnol. Oceanogr., 42(1), pp.1-20.

3 ) Eppley, R.W., 1972, Temperature and phytoplankton growth in the sea. Fish. Bull. 70 : pp. 1063-1085.

4 ) Platt, T., 1986, Primary production of the ocean water column as a function of surface light intensity: Algorithms for remote sensing. Deep-Sea Res., 33, pp.149-163.
5 ) Saba, V.S., M.A.M. Friedrichs, D. Antoine, R.A. Armstrong, I. Asanuma, M.J. Behrenfeld, A.M. Ciotti, M. Dowell, N. Hoepffner, K.J.W. Hyde, J. Ishizaka, T. Kameda, J. Marra, F. M'elin, A. Morel, J. O’Reilly, M. Scardi, W.O. Smith Jr., T.J. Smyth, S. Tang, J. Uitz, K. Waters, and T.K. Westberry, 2011, An evaluation of ocean color model estimates of marine primary productivity in coastal and pelagic regions across the globe, Biogeosciences, 8, 489-503, doi : 10.5194/bg-8-489 -2011 .

6 ) Shiomoto, A., S. Hashimoto, and T. Murakami, 1998, Primary Productivity and Solar Radiation Off Sanriku in May 1997, J. of Oceanography, 54, pp.539-544.

$7)$ Turk, D., C.S. Meinen, D. Antoine, M.J. McPhaden, and M.R. Lewis, 2011, Implications of changing El Niño patterns for biological dynamics in the equatorial Pacific Ocean, Geophys. Res. Lett., 38, L23603, doi : 10.1029/ 2011GL049674. 